\title{
Trade-Finance Nexus: Was it Distorted in the Aftermath of the Global Financial Crisis?
}

\author{
Marta Wajda-Lichy, Paweł Kawa
}

\section{A B S T R A C T}

Objective: The objective of this article is to examine whether the trade-finance nexus was distorted in the aftermath of the global financial crisis.

Research Design \& Methods: We estimated OLS regressions between trade and finance for 36 countries. The Quandt-Andrews breakpoint test and Bai-Perron multiple breaking point test were used to test for structural breaks in the trade-finance nexus.

Findings: The results show that a structural break in the trade-finance relationship occurred in 2008 in the majority of the examined countries. The structural changes were relatively more often identified in middle-income countries than in high-income ones. This finding confirms our suppositions inferred from the stylized facts that reactions of international trade and financial development in the crisis era differed across the countries depending on their level of development.

Implications \& Recommendations: Our study partly fills the gap between theory-based approaches to the trade-finance nexus and empirical evidence. It also emphasizes the need of a revision of traditional theoretical arguments, including those referring to the linkages between the financial and the real sides of economy.

Contribution \& Value Added: Our article contributes to the theoretical discussion in three ways. Firstly, we examine a still bothering question on the relationship between the financial and the real sides of economy. Secondly, while the main strand in the literature deals with finance-growth and trade-growth interactions, we focus directly on the trade-finance linkages. Thirdly, our finding that a break in the trade-finance nexus was more pronounced for the middle-income countries may provide some insight into better understanding of the global financial crisis of 2008 and its consequences.

\section{Article type: research article}

Keywords:

financial development; international trade; trade-finance nexus; financial crisis

JEL codes: $\quad$ F10, F11, F40, G10

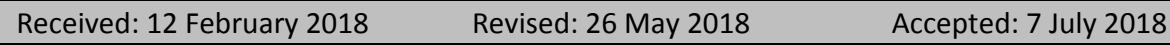

\section{Suggested citation:}

Wajda-Lichy, M., \& Kawa, P. (2018). Trade-Finance Nexus: Was it Distorted in the Aftermath of the Global Financial Crisis?. Entrepreneurial Business and Economics Review, 6(3), 11-27. https://doi.org/10.15678/EBER.2018.060301 


\section{INTRODUCTION}

It is widely confirmed that trade openness and financial development are relevant determinants of economic growth. Extensive literature on trade-growth (e.g. Dollar \& Kraay, 2003; Frankel \& Romer, 1999; Edwards, 1998) and finance-growth linkages (e.g. King \& Levine, 1993; Dornbusch \& Reynoso, 1989; Levine, Loayza, \& Beck, 2000; Wachtel, 2003) explores the mechanisms through which these two factors influence growth.

Classical arguments for international openness date back to Adam Smith's analysis of production specialization based on absolute advantages and David Ricardo's theory of comparative advantages. Both approaches emphasise that openness promotes efficient allocation of production factors and leads to wealth increase. Traditional theories of trade also indicate that outward-oriented countries enable enterprises to exploit economies of scale. Neo-classical theories of growth confirm higher effectiveness of resources allocation in open economies, underlining the role of international trade in promoting competitiveness and dissemination of knowledge and technological progress (Frankel \& Romer, 1999). There are also arguments for learning-by-doing effects which occur through both export and import channels (Baldwin \& Gu, 2004).

Modern theories of economic growth, as well as empirical studies reveal, however, that growth effects of trade openness should not be taken for granted. They may depend on a variety of structural characteristics, including the level of competitiveness and development (Helpman, 1984; Helpman \& Krugman, 1985; Bahgwati \& Srinivasan, 2001), market flexibility, institutional quality (Acemoglu, Johnson, \& Robinson, 2005) or the political environment (Bordo \& Rousseau, 2012; Rajan \& Zingales, 2003). Rodrik (1992) claims that trade openness may cause macroeconomic uncertainty and thereby lead to macro-level shocks which undermine growth. These arguments are formulated neither against open-oriented economies, nor in favour of autarky. Instead, they rather explain ambiguous effects of tradeled growth strategies adopted by different countries at different times.

The history of theoretical and empirical research on financial development and economic growth extends into the second part of the 19th century. A well-developed financial sector was commonly regarded as favourable for accelerating growth by increased accumulation of savings, stimulating investment through lower cost of capital, more adequate investment projects appraisal, and better risk management (Schumpterer, 1934; King \& Levine, 1993; Dornbusch \& Reynoso, 1989). Also from a political economy perspective, financial development was traditionally considered as a 'key to growth' (Hoenig, 1995). However, some economists (e.g. Robinson, 1952; Lucas, 1988) point out a possible reverse causal link: it is not a well-developed financial system which fuels economic growth, but it is economic growth which generates demand for financial services and determines how well the system of financial intermediation is developed.

The recent global financial crisis evoked a renewed interest in financial markets' impact on economic growth. As the crisis had its origins in substantial turbulences experienced in financial markets, more emphasis was put on identifying negative consequences of development or 'over-development' of financial markets. The main concern which arises is that some countries may have 'too large' financial systems in relation to the size of their real economies that could make them more vulnerable to disturbances. The global crisis also exposed a foreign trade as an important channel of shocks transmission across countries. 
A sudden collapse in trade in 2009 , then its short-term recovery (both of them much more intensive than the concurrent changes in GDP), and finally a 'trade plateau' observed since 2012 imply that these disturbances were caused not only by demand factors.

Despite a wide range of theoretical and empirical evidence on how foreign trade and financial development affect growth, the interactions between trade and finance are still relatively rarely discussed in literature. The perturbations caused by the financial crisis induce to rethink the trade-finance nexus both from theoretical and empirical perspective.

The aim of our article is to examine whether the trade-finance nexus was distorted during the last financial crisis of 2008. We also want to test whether changes in international trade and financial development were different in the middle- and the highincome countries. In our interpretation of the findings, we refer to a theoretical background and empirical evidence of the trade-finance nexus.

The article is divided into the following sections. We start with the theoretical aspects of the trade-finance linkages. Then, we present data and methods of our research. This section consists of two parts. In the first one, we report on trade openness and financial development in the period 1993-2016 and present the stylized facts for the two groups of countries: the middle- and the high-income economies. In the second one, we focus on quantitative methods used to test for structural breaks in the trade-finance nexus. Then, we present and discuss the results of two statistical tests applied in our research. The conclusions are formulated in the last part of the article.

\section{LITERATURE REVIEW}

A traditional approach to the trade-finance linkages indicates that trade and financial development are complementary. This relationship is described by two hypotheses which stand for the directions of the causalities between these two variables.

The first one, known as a demand-following hypothesis, reflects the causality from trade to finance. It can be justified with a claim that real economy needs finance. In other words, demand for financial services should induce financial development. This hypothesis is supported by Robinson (1952) who pointed that 'where enterprise leads, finance follows'. It is worth adding that the real sector uses external sources not only for financing direct production activity, but also for promotion, research, and training expenditure. In open economies demand for credits or other financial instruments is expected to be larger because of the specificity of cross-border transactions. Firstly, both exporters and importers require financial instruments to hedge their transactions against external risks, like exchange rate fluctuations, transport damages or delays. Secondly, demand for finance is a consequence of higher competition from foreign enterprises. To build comparative advantages and deal with higher foreign competition domestic producers need reliable, adequate and efficient financing, both long-term (for investment and human capital development) and short-term (for current cross-border transactions and production processing). Thirdly, as export producers want to exploit economies of scale they need more external financing to undertake new investments and research. Some economists, e.g. Beck $(2002,2003)$ and Rajan and Zingales (2003), found that the causality running from trade to finance development is indeed significant. Their research contributed to an important strand of the literature on trade openness and finance nexus, underlining the role of political economy in the financial development. 
The second approach to the trade-finance nexus, known as a supply-leading hypothesis, indicates causality from finance to trade. It was formulated in the finance-growth literature, suggesting a positive impact of finance on economic growth, but then it was extended to other implications of finance, e.g. for international trade. It suggests that well developed financial markets may constitute a source of comparative advantages for the foreign traders, thus enhancing trade and increasing openness of the economy. The starting point of a discussion could be an argument put forward by Schumpeter that financial services support savings and investments and are necessary to foster economic growth (Schumpeter, 1934). Referring to the Schumpeterian concept of creative destruction, King and Levine (1993) underline the influence of a financial system on entrepreneurship. They define four channels of that influence, that may extend trade capacities: selecting the most promising investment projects, employing resources to fund well-auguring projects, enabling investors to diversify their risks and finally, exposing potential additional benefits of innovations. According to Beck et al. (2009), credit removes financing constraints that otherwise exporters would have to face, thus leading to greater investments and potentially greater exports. Using fundamentals of the Greenwood and Jovanovic (1989) model with an endogenous financial system, Acemoglu (2009) confirmed that financial intermediation lowers costs and increases rate of return on capital. According to Greenwald, Salinger and Stiglitz (1992), financial development eliminates some market failures and reduces high risks typical for technologically advanced projects which are a source of country's competitiveness. This argument is shared by Chang, Hung and Lu (2005) who explored the possible relevance of financial development and R\&D activities in promoting international trade. Manova (2013) stated that limited financial development does not only restrict trade by lowering output, but it also disrupts trade by precluding potentially profitable firms from exporting (extensive margin) and restricting exporters' sales abroad (intensive margin). In his empirical work Beck (2002) confirmed that the mature financial markets induce higher volume of trade, as well as influence its structure. Some other empirical findings basically lend support to the supply-leading hypothesis (Hur, Raj, \& Riyanto, 2006; Becker, Chen, \& Greenberg, 2013). Although the link between financial development and exports would also suggest a positive impact of finance on imports, the related empirical findings either do not explicitly examine the effect on imports or find a considerably weaker impact of finance on imports than on exports (Beck, 2002).

Analysing theoretical background of the trade-finance nexus, a bi-directional causality should also be discussed. It means that finance and trade can be mutually dependent. In other words, the real sector demand for financial services induces financial development and vice versa, i.e. the well-developed financial system is a pre-condition for trade openness. Aizenman and Noy (2009) constructed a theoretical framework leading to two-way feedbacks between finance and trade openness and identify these linkages empirically. The authors focused on bi-directional causalities between de jure and de facto financial and trade openness. They confirmed the importance of the lagged trade openness in Granger-causing financial openness, as well as the significance of the lagged financial openness in accounting for trade openness. A bi-directional causality was also examined in the seminal paper of Bordo and Rousseau (2012). They analysed 17 high-income economies over the period 18802004 using a sum of exports and imports to GDP as a measure of trade openness and a ratio of broad money (aggregate M2) to GDP as a proxy for financial development. For the final 
sub-period 1960-2004, the financial development was proxied by a ratio of private credit to GDP. The authors explored that bi-directional causalities occurred before 1930, but after 1945 these linkages do not persist. Bordo and Rousseau (2012) concluded that due to the changes in the macroeconomic and political environment, trade and finance may settle into a new equilibrium, where outside factors dive the relationship between them more than mutually reinforcing effects. A general approach to bi-directional causality is reflected in Rodrik et al. (2004) figure which helps to analyse interdependencies between institutional, geographical and trade related factors in determining income level.

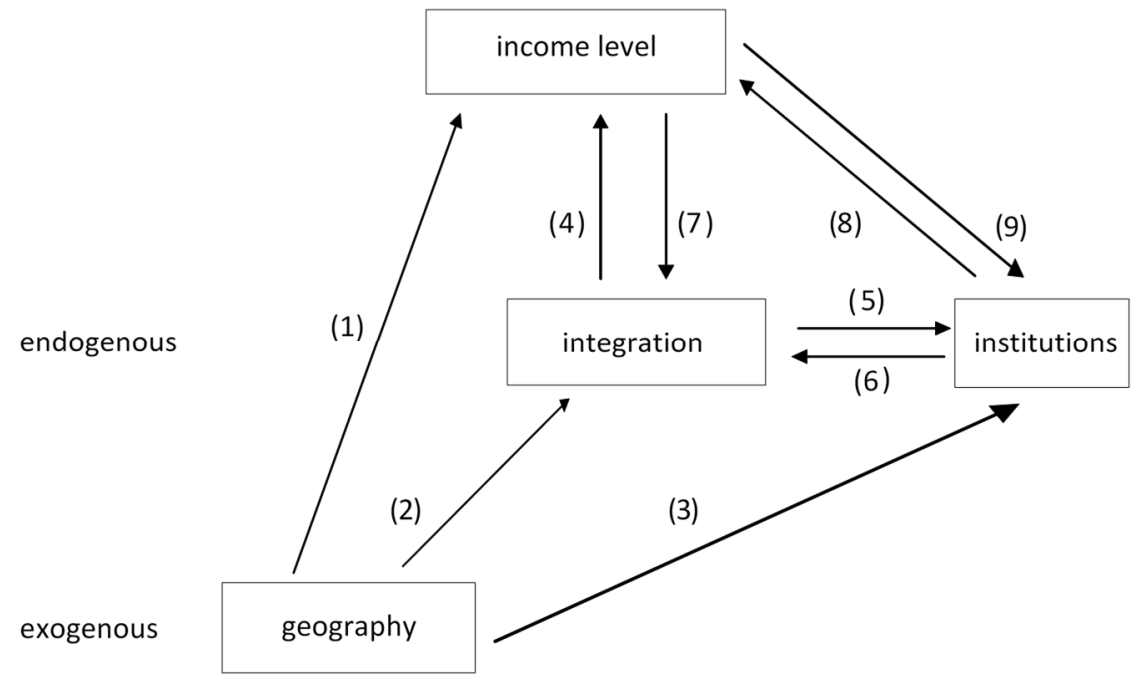

Figure 1. The 'deep' determinants of income Source: Rodrik et al. (2004).

Rodrik et al. (2004) suggest three-fold classification of income determinants: geography, integration which is related to trade openness, and institutions which include a quality of financial system. Long-term development is a complex phenomenon and one of the fundamental difficulties lies in sorting out a complex web of causalities. Figure 1 shows that the only exogenous determinant is geography. The extent to which an economy is integrated with the rest of the world and the quality of its institutions are both endogenous. The arrows 5 and 6 going in opposite directions indicate bi-directional causalities between these two factors. These interactions should be considered by researchers trying to identify channels through which trade and finance influence economic growth.

Having reviewed the relevant literature we conclude that the empirical studies provide ambiguous results on the predominance of any of the above-mentioned hypotheses related to trade openness and financial development nexus. Some economists confirm that financially developed countries trade more (Beck, 2002; Manova, 2013; Becker et al., 2013), whereas others emphasize weak or conditioned causality from finance to trade (Chang, Kaltani, \& Loayza, 2009; Menyah, Nazlioglu, \& Wolde-Rufael, 2014). There is also evidence of links from international openness to finance, which is conditioned on economic or political institutions (Rajan \& Zingales, 2003; Baltagi, Demetriades, \& Law, 2009; Bordo \& Rousseau, 2012; Zhang, Zhu, \& Lu, 2015). 


\section{MATERIAL AND METHODS}

\section{Preliminary Observations: Stylized Facts on Trade Openness and Financial Development}

Before applying statistical tests to identify structural breaks in the trade-finance relationship we present the stylized facts on trade openness and financial development in highand middle-income countries over the period 1993-2016. We use aggregates from the World Bank database. According to the World Bank classification, the group of high-income countries comprises the economies with GNI per capita equal to USD 12235 or more. The group of middle-income countries includes lower-middle and upper-middle ones. We refer to upper-middle economies which are classified by the World Bank as countries with GNI per capita between USD 3956 and USD 12235.

One of the most striking aspects of the crisis was a sharp collapse in trade in 2009. The average annual declines in exports reached $11 \%$ in high-income countries and $9 \%$ in middle-income ones. Reductions in imports were even stronger, reaching $12 \%$ and $14 \%$, respectively (Figures 2 and 3 ).

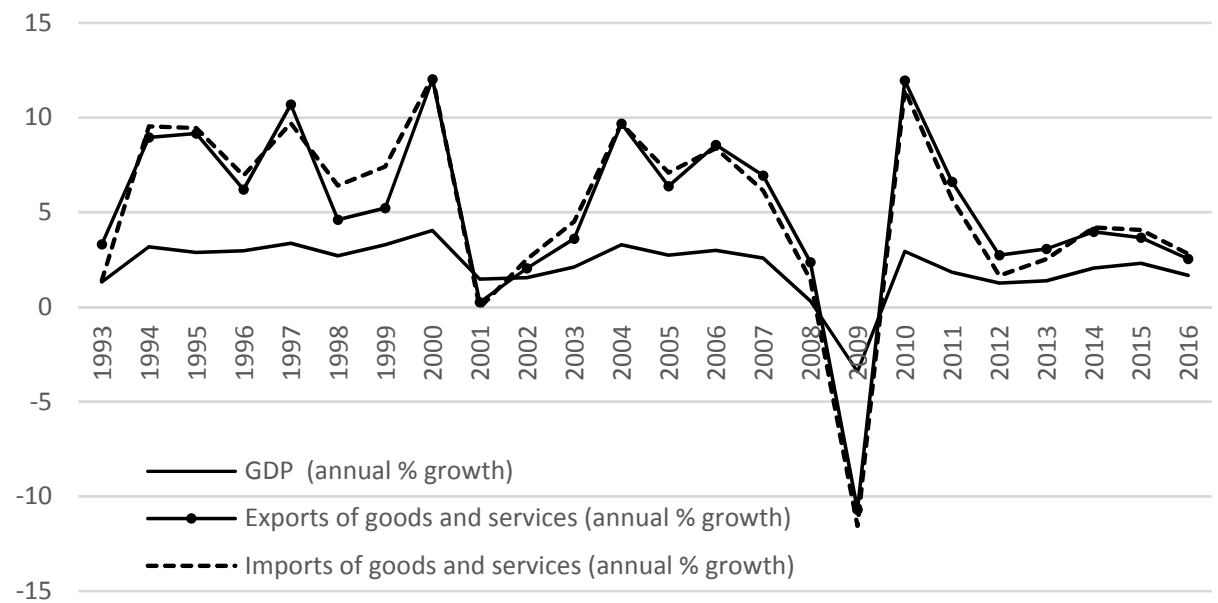

Figure 2. Exports, imports and GDP: annual rates of growth in high-income countries over the period 1993-2016

Source: own elaboration based on the World Bank data available on http://databank.worldbank.org/data/

It is easy to notice that in the both groups of countries the fluctuations in exports and imports were higher than changes of GDP. In 2009, a reduction of the GDP growth was extremely big, however exports and imports diminished even more. Such uneven changes affected both groups of countries and contributed to the deterioration of their trade openness.

Figures 4 and 5 present an index of openness which in 2009 declined significantly in the two groups of countries. Trade openness is measured as a sum of exports and imports divided by GDP. Figures 4 and 5 present also financial development which is proxied by domestic credit to private sector by banks in relation to GDP. The two groups of countries differ significantly in their level of financial development. In the mid-1990s, financial markets in high-income economies were almost twice as deep as in middle-income countries. 
In 2008, the average financialization in rich economies reached nearly $100 \%$ of GDP ${ }^{1}$, whereas in middle-income economies the level of financial development was around $60 \%$ of GDP. It is interesting that since 2009 credit-to-GDP ratio has been decreasing in highincome countries, whereas in middle-income economies it has been increasing. This preliminary observation suggests that trade openness and finance behaved differently in these two groups of countries. A break in trade-finance linkages during the financial crisis of 2008 seems to be more pronounced for middle-income countries.

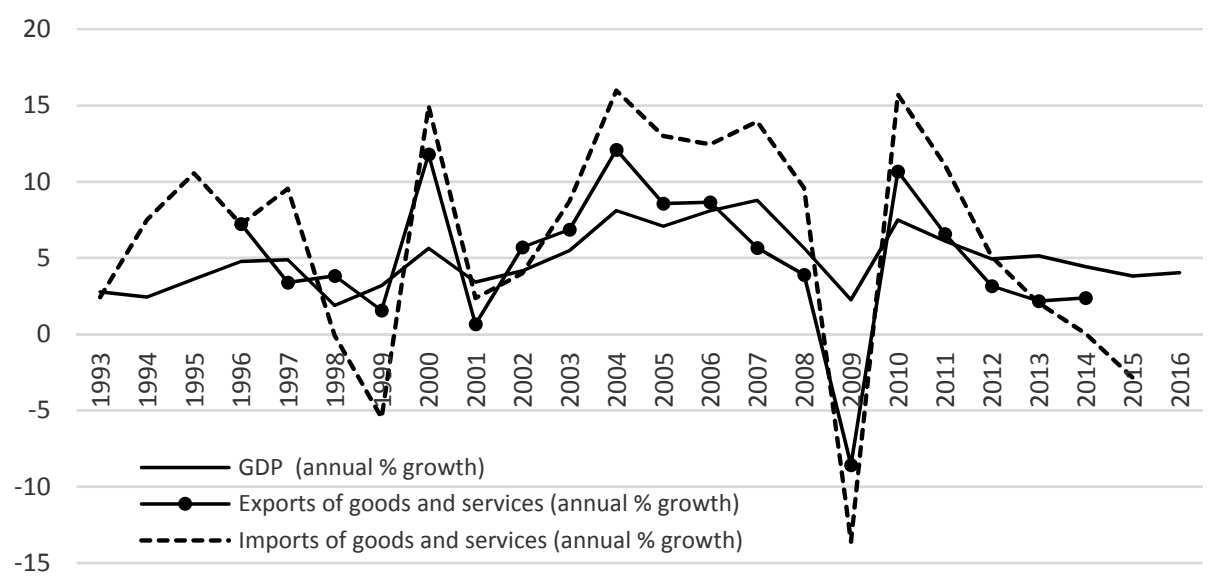

Figure 3. Exports, imports and GDP: annual rates of growth in middle-income countries over the period 1993-2016

Source: own elaboration based on the World Bank data available on http://databank.worldbank.org/data/
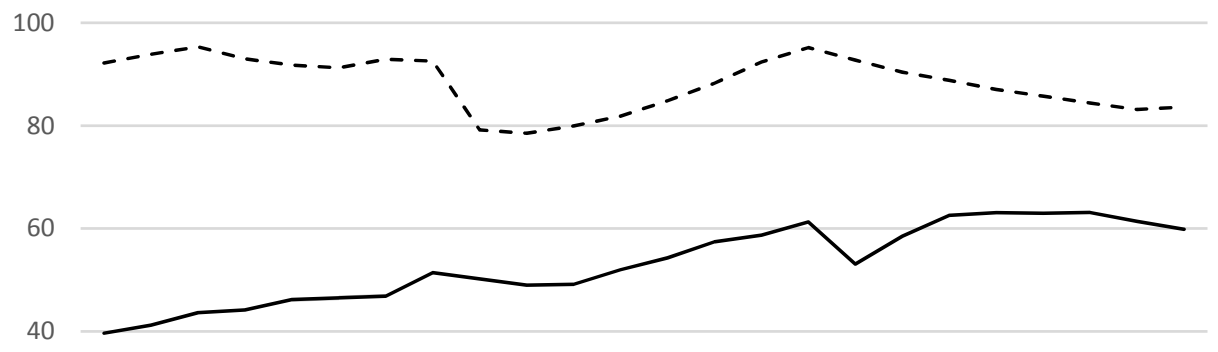

- - - Domestic credit to private sector by banks (\% of GDP) — Trade (\% of GDP)

20

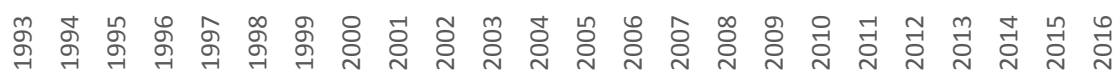

Figure 4. Trade openness and financial development in high-income countries over the period 1993-2016

Source: own elaboration based on the World Bank data available on http://databank.worldbank.org/data/

\footnotetext{
${ }^{1}$ Some countries, however, had significantly higher indices of financial development. In the United Kingdom domestic credit provided to the private sector by banks amounted for almost $200 \%$ of GDP, in Denmark, Spain, Ireland, Portugal, Switzerland and Korea it was more than 150\% of GDP. When proxing financial development with the use of domestic credit to private sector Cyprus, Iceland, the United Kingdom and Denmark reached about $200 \%$ of their GDP, the United States, Japan, Spain, Ireland, Portugal and Switzerland more than $150 \%$, respectively.
} 


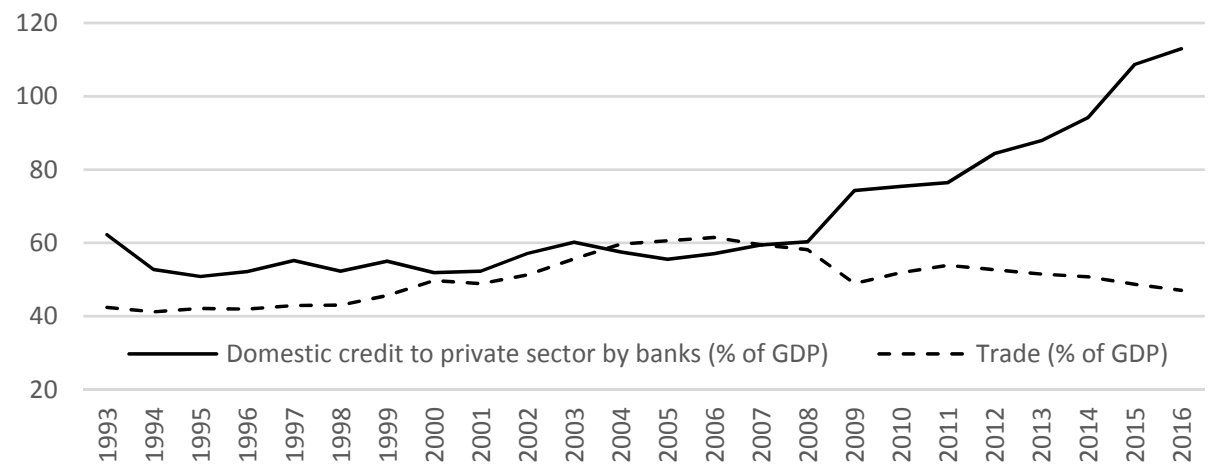

Figure 5. Trade openness and financial development in the middle-income countries over the period 1993-2016

Source: own elaboration based on the World Bank data available on http://databank.worldbank.org/data/

\section{Statistical Tests on Structural Break in the Trade-Finance Nexus}

To analyse whether the trade-finance nexus was distorted during the crisis era we tested changes in trade openness and financial development for 36 countries, comprising 15 middle-income economies and 21 high-income economies. We assigned a particular country to one of these groups if for most of the period under consideration it belonged, according to the World Bank classification, to this group.

For each country we estimated simple OLS regressions reflecting the relationship between trade openness and financial development. The former was approximated by exports and the latter was measured by domestic credit to private sector by banks as a percentage of GDP. The growth rate of exports was set as a dependent variable, and all of the regressions were calculated with a constant term. It is worth noting that this simple approach does not allow us to definitively infer on the direction of the trade-finance nexus, as we do not control for potential confounding factors. It also does not involve any explicit tests for causality. However, it provides us with a framework to track changing interdependencies between trade and finance, both before and after the global financial crisis, and examine whether parameters of the models are stable across different data subsamples. The quarterly data calculated as changes to the same period of the previous year was taken from the OECD and BIS databases. We examined the period of 1992Q1-2017Q3 for the middle-income countries and 1990Q1-2017Q3 for the high-income countries. After obtaining estimation results and regression residuals the breakpoints tests were performed both for constant terms and coefficients. We do not choose a priori any dates of a potential structural break for each regression, but rather refer to the procedures that facilitate detection of previously unspecified dates marking the shift in the nexus under investigation.

The Quandt-Andrews breakpoint test was applied to test for unknown structural breakpoints. It is based on a multiple application of the Chow test. The idea of the breakpoint Chow test is to fit the equation separately for each subsample and to see whether there are significant differences in the parameters of estimated equations. A significant difference indicates a structural change in the relationship. The idea behind the Quandt- 
Andrews test is that a single Chow breakpoint test is performed at every observation between each possible pair of dates in the sample. The test statistics from these Chow tests are then summarised into one test statistic for a test of the null hypothesis of no breakpoints (Andrews, 1993). The null hypothesis was formulated as follows: there are no breakpoints within $15 \%$ trimmed data (symmetrically $15 \%$ of observations from the beginning and from the end of the estimation sample were excluded).

Bai-Perron multiple breakpoint test (Bai \& Perron, 1998) was used as an extension of the Quandt-Andrews framework by allowing for multiple unknown breakpoints. It is an intuitive approach for detecting more than one break which involves sequential application of breakpoint tests. Thus sequential (one-by-one) rather than simultaneous estimation of multiple breaks is investigated. It starts with the full sample and performs a test of the constancy with an unknown break. If the test rejects the null hypothesis of the constancy, the break date is identified, the sample is divided into two subsamples and a single unknown breakpoint test is performed in each subsample (error distributions differences are allowed across breaks what provides robustness of the test to error heterogeneity). Each of these tests may be viewed as a test of the alternative of $L+1$ breaks versus the null hypothesis of $L$ breaks. The procedure we applied was repeated until all of the subsamples do not reject the null hypothesis at a significance level of 0.05. The critical values were taken from Bai and Perron (2003).

\section{RESULTS AND DISCUSSION}

The test results are presented in Table 1 for the middle-income countries and in Table 2 for the high-income ones. According to the Quandt-Andrews test, the Maximum LR F-statistic fails to reject the null hypothesis of no structural breaks for almost all of the considered countries, which allows to expect that the structural change in the trade-finance nexus occurred. The maximum statistic was computed in the vast majority of the countries in 2008Q4, and that is the most likely breakpoint location. The breakpoint date indicates a structural change in the trade-finance nexus and a start of a new regime.

Table 1. Break dates in trade-finance nexus in the middle-income countries

\begin{tabular}{|c|c|c|c|c|c|c|}
\hline \multirow[b]{2}{*}{ Country } & \multirow{2}{*}{$\begin{array}{c}\text { Data range* } \\
\text { (Equation } \\
\text { Sample) }\end{array}$} & \multicolumn{2}{|c|}{ Quandt-Andrews test } & \multicolumn{3}{|c|}{ Bai-Perron test } \\
\hline & & $\begin{array}{c}\text { Max LR } \\
\text { F-statistic }\end{array}$ & Breakpoint & Break test & $\begin{array}{c}\text { Scaled } \\
\text { F-statistic }\end{array}$ & $\begin{array}{l}\text { Break dates } \\
\text { (sequential) }\end{array}$ \\
\hline \multirow{2}{*}{ Argentina } & \multirow{2}{*}{ 1993Q1-2017Q3 } & 13.3671 & \multirow{2}{*}{ 2002Q3 } & 0 vs. 1 & 26.2490 & $2002 Q 3$ \\
\hline & & $(0.0000)$ & & 1 vs. 2 & 17.1680 & 2008Q2 \\
\hline \multirow{3}{*}{ Brazil } & \multirow{3}{*}{ 1997Q1-2017Q3 } & \multirow{3}{*}{$\begin{array}{l}13.5915 \\
(0.0000)\end{array}$} & \multirow{3}{*}{ 2012Q2 } & 0 vs. 1 & 50.1187 & 2012Q2 \\
\hline & & & & 1 vs. 2 & 15.0318 & 2008Q2 \\
\hline & & & & 2 vs. 3 & 46.2162 & $2002 Q 3$ \\
\hline \multirow{3}{*}{ Chile } & \multirow{3}{*}{ 1997Q1-2017Q3 } & \multirow{3}{*}{$\begin{array}{c}8.2996 \\
(0.0056)\end{array}$} & \multirow{3}{*}{$2008 Q 4$} & 0 vs. 1 & 18.4126 & $2008 Q 4$ \\
\hline & & & & 1 vs. 2 & 45.0272 & 2004Q1 \\
\hline & & & & 2 vs. 3 & 18.3039 & 2001Q1 \\
\hline \multirow{3}{*}{ China } & \multirow{3}{*}{ 1993Q1-2017Q3 } & \multirow{3}{*}{$\begin{array}{c}8.4329 \\
(0.0049)\end{array}$} & \multirow{3}{*}{ 2008Q2 } & 0 vs. 1 & 17.6614 & $2008 Q 2$ \\
\hline & & & & 1 vs. 2 & 31.4508 & 1999Q4 \\
\hline & & & & 2 vs. 3 & 15.0585 & $2003 Q 2$ \\
\hline
\end{tabular}




\begin{tabular}{|c|c|c|c|c|c|c|}
\hline \multirow[b]{2}{*}{ Country } & \multirow{2}{*}{$\begin{array}{c}\text { Data range* } \\
\text { (Equation } \\
\text { Sample) }\end{array}$} & \multicolumn{2}{|c|}{ Quandt-Andrews test } & \multicolumn{3}{|c|}{ Bai-Perron test } \\
\hline & & $\begin{array}{c}\text { Max LR } \\
\text { F-statistic }\end{array}$ & Breakpoint & Break test & $\begin{array}{c}\text { Scaled } \\
\text { F-statistic }\end{array}$ & $\begin{array}{l}\text { Break dates } \\
\text { (sequential) }\end{array}$ \\
\hline \multirow{3}{*}{ Colombia } & \multirow{3}{*}{ 1995Q4-2017Q3 } & \multirow{3}{*}{$\begin{array}{l}28.3110 \\
(0.0000)\end{array}$} & \multirow{3}{*}{ 2012Q2 } & 0 vs. 1 & 87.4612 & $2012 Q 2$ \\
\hline & & & & 1 vs. 2 & 28.0703 & $2003 Q 3$ \\
\hline & & & & 2 vs. 3 & 17.2572 & 1999Q3 \\
\hline \multirow{3}{*}{$\begin{array}{l}\text { Czech } \\
\text { Republic }\end{array}$} & \multirow{3}{*}{ 1994Q1-2017Q3 } & \multirow{3}{*}{$\begin{array}{l}18.5788 \\
(0.0000)\end{array}$} & \multirow{3}{*}{$2008 Q 4$} & 0 vs. 1 & 34.4082 & 2008Q4 \\
\hline & & & & 1 vs. 2 & 20.6079 & 1998Q4 \\
\hline & & & & 2 vs. 3 & 21.0472 & 2005Q2 \\
\hline \multirow{2}{*}{ Hungary } & \multirow{2}{*}{ 1993Q1-2017Q3 } & 28.0249 & \multirow{2}{*}{$2008 Q 4$} & 0 vs. 1 & 48.7774 & $2008 Q 4$ \\
\hline & & $(0.0000)$ & & 1 vs. 2 & 58.7964 & 2012Q2 \\
\hline India & 1993Q1-2017Q3 & $\begin{array}{c}8.5577 \\
(0.0044)\end{array}$ & 2012Q1 & 0 vs. 1 & 34.1214 & 2012Q1 \\
\hline \multirow{2}{*}{ Indonesia } & \multirow{2}{*}{ 1993Q1-2017Q3 } & \multirow{2}{*}{$\begin{array}{c}8.5953 \\
(0.0043)\end{array}$} & \multirow{2}{*}{ 2012Q2 } & 0 vs. 1 & 27.6426 & 2012Q2 \\
\hline & & & & 1 vs. 2 & 15.0557 & 2004Q3 \\
\hline \multirow{3}{*}{ Korea } & \multirow{3}{*}{ 1993Q1-2017Q3 } & \multirow{3}{*}{$\begin{array}{l}14.7983 \\
(0.0000)\end{array}$} & \multirow{3}{*}{ 2008Q4 } & 0 vs. 1 & 35.2556 & 2008Q4 \\
\hline & & & & 1 vs. 2 & 18.7406 & $2002 Q 3$ \\
\hline & & & & 2 vs. 3 & 52.6228 & 1998Q2 \\
\hline \multirow{2}{*}{ Mexico } & \multirow{2}{*}{ 1993Q1-2017Q3 } & \multirow{2}{*}{$\begin{array}{l}16.9380 \\
(0.0000)\end{array}$} & \multirow{2}{*}{ 2008Q4 } & 0 vs. 1 & 27.1914 & 2008Q4 \\
\hline & & & & 1 vs. 2 & 47.9863 & 2001Q1 \\
\hline \multirow{2}{*}{ Poland } & \multirow{2}{*}{ 1993Q1-2017Q3 } & 23.0481 & \multirow{2}{*}{ 2008Q4 } & 0 vs. 1 & 51.4236 & $2008 Q 4$ \\
\hline & & $(0.0000)$ & & 1 vs. 2 & 63.1984 & 2002Q4 \\
\hline \multirow{3}{*}{ Russia } & & & & 0 vs. 1 & 25.6690 & 2008Q4 \\
\hline & 1996Q2-2017Q3 & 12.4535 & $2008 Q 4$ & 1 vs. 2 & 47.7416 & $2002 Q 4$ \\
\hline & & & & 2 vs. 3 & 52.2234 & 1999Q4 \\
\hline & & & & 0 vs. 1 & 108.6732 & $2010 Q 1$ \\
\hline South Af- & $100301-201702$ & 27.4950 & ل10 & 1 vs. 2 & 18.8208 & 2006Q3 \\
\hline & $199301-\angle 01 / 03$ & $(0.0000)$ & 201001 & 2 vs. 3 & 42.6226 & 2002Q4 \\
\hline & & & & 3 vs. 4 & 20.2237 & 1997Q3 \\
\hline & & & & 0 vs. 1 & 41.3264 & $2008 Q 4$ \\
\hline Turkey & 1993Q1-2017Q3 & $\begin{array}{l}19.6161 \\
(0.0000)\end{array}$ & 2008Q4 & 1 vs. 2 & 45.9187 & 2002Q2 \\
\hline & & & & 2 vs. 3 & 41.1445 & 2012Q2 \\
\hline
\end{tabular}

Notes: *differences in data range result from data availability.

p-values in parentheses; both tests with 15\% trimmed data; Bai-Perron test significant on 0.05 level.

Source: own calculations in EViews 10.

Table 2. Break dates in trade-finance nexus in the high-income countries

\begin{tabular}{|c|c|c|c|c|c|c|}
\hline \multirow[b]{2}{*}{ Country } & \multirow{2}{*}{$\begin{array}{c}\text { Data range* } \\
\text { (Equation Sample) }\end{array}$} & \multicolumn{2}{|c|}{ Quandt-Andrews test } & \multicolumn{3}{|c|}{ Bai-Perron test } \\
\hline & & $\begin{array}{c}\text { Max LR } \\
\text { F-statistic }\end{array}$ & Breakpoint & Break test & $\begin{array}{c}\text { Scaled } \\
\text { F-statistic }\end{array}$ & $\begin{array}{l}\text { Break dates } \\
\text { (sequential) }\end{array}$ \\
\hline \multirow{2}{*}{ Australia } & \multirow{2}{*}{ 1991Q1-2017Q3 } & 38.8697 & \multirow{2}{*}{$2010 Q 3$} & 0 vs. 1 & 71.1055 & $2010 Q 3$ \\
\hline & & $(0.0000)$ & & 1 vs. 2 & 21.3618 & 1997Q2 \\
\hline \multirow{2}{*}{ Austria } & \multirow{2}{*}{ 1991Q1-2017Q3 } & 26.5458 & \multirow{2}{*}{$2011 Q 4$} & 0 vs. 1 & 69.6271 & $2011 Q 4$ \\
\hline & & $(0.0000)$ & & 1 vs. 2 & 14.2886 & 200704 \\
\hline \multirow{4}{*}{ Belgium } & \multirow{4}{*}{ 1991Q1-2017Q3 } & \multirow{4}{*}{$\begin{array}{l}17.1244 \\
(0.0000)\end{array}$} & \multirow{4}{*}{ 2008Q4 } & 0 vs. 1 & 29.0423 & $2008 Q 4$ \\
\hline & & & & 1 vs. 2 & 49.8944 & $2012 Q 4$ \\
\hline & & & & 2 vs. 3 & 45.3290 & $2002 Q 3$ \\
\hline & & & & 3 vs. 4 & 15.4764 & 1996Q1 \\
\hline
\end{tabular}




\begin{tabular}{|c|c|c|c|c|c|c|}
\hline \multirow[b]{2}{*}{ Country } & \multirow{2}{*}{$\begin{array}{c}\text { Data range* } \\
\text { (Equation Sample) }\end{array}$} & \multicolumn{2}{|c|}{ Quandt-Andrews test } & \multicolumn{3}{|c|}{ Bai-Perron test } \\
\hline & & $\begin{array}{c}\text { Max LR } \\
\text { F-statistic }\end{array}$ & Breakpoint & Break test & $\begin{array}{c}\text { Scaled } \\
\text { F-statistic }\end{array}$ & $\begin{array}{l}\text { Break dates } \\
\text { (sequential) }\end{array}$ \\
\hline Canada & 1991Q1-2017Q3 & $\begin{array}{c}7.0972 \\
(0.0162) \\
\end{array}$ & $2011 Q 4$ & 0 vs. 1 & 17.7132 & $2011 Q 4$ \\
\hline Denmark & 1991Q1-2017Q3 & $\begin{array}{l}13.7502 \\
(0.0000)\end{array}$ & $2008 Q 4$ & $\begin{array}{l}0 \text { vs. } 1 \\
1 \text { vs. } 2 \\
2 \text { vs. } 3 \\
3 \text { vs. } 4 \\
\end{array}$ & $\begin{array}{c}24.0986 \\
53.9370 \\
15.8902 \\
8.5968 \\
\end{array}$ & $\begin{array}{l}2008 Q 4 \\
2002 Q 2 \\
2013 Q 4\end{array}$ \\
\hline Finland & 1991Q1-2017Q3 & $\begin{array}{l}13.0920 \\
(0.0001)\end{array}$ & 1996Q1 & $\begin{array}{l}0 \text { vs. } 1 \\
1 \text { vs. } 2 \\
2 \text { vs. } 3\end{array}$ & $\begin{array}{l}35.4553 \\
26.8089 \\
72.4845\end{array}$ & $\begin{array}{l}\text { 1996Q1 } \\
2008 Q 4 \\
2002 Q 3\end{array}$ \\
\hline France & 1991Q1-2017Q3 & $\begin{array}{c}7.3327 \\
(0.0132)\end{array}$ & $2008 Q 4$ & $\begin{array}{l}0 \text { vs. } 1 \\
1 \text { vs. } 2\end{array}$ & $\begin{array}{l}13.2953 \\
31.3606\end{array}$ & $\begin{array}{l}2008 Q 4 \\
2002 Q 4\end{array}$ \\
\hline Germany & 1991Q1-2017Q3 & $\begin{array}{l}23.2214 \\
(0.0000)\end{array}$ & 2008Q4 & $\begin{array}{l}0 \text { vs. } 1 \\
1 \text { vs. } 2\end{array}$ & $\begin{array}{c}44.4457 \\
9.9971 \\
\end{array}$ & 2008Q4 \\
\hline Greece & 1991Q1-2017Q3 & $\begin{array}{c}5.0050 \\
(0.0943)\end{array}$ & 1995Q4 & 0 vs. 1 & - & - \\
\hline Ireland & 1991Q1-2017Q3 & $\begin{array}{l}22.8422 \\
(0.0000)\end{array}$ & 2008Q4 & $\begin{array}{l}0 \text { vs. } 1 \\
1 \text { vs. } 2\end{array}$ & $\begin{array}{l}55.8165 \\
20.1530\end{array}$ & $\begin{array}{l}2008 Q 4 \\
2013 Q 4\end{array}$ \\
\hline Italy & 1991Q1-2017Q3 & $\begin{array}{l}10.8428 \\
(0.0005) \\
\end{array}$ & $2000 Q 1$ & $\begin{array}{l}0 \text { vs. } 1 \\
1 \text { vs. } 2 \\
\end{array}$ & $\begin{array}{l}31.7353 \\
14.6309 \\
\end{array}$ & $\begin{array}{l}\text { 2000Q1 } \\
\text { 2008Q4 }\end{array}$ \\
\hline Japan & 1991Q1-2017Q3 & $\begin{array}{c}5.2810 \\
(0.0755) \\
\end{array}$ & 2012Q3 & 0 vs. 1 & 36.0198 & $2013 Q 4$ \\
\hline $\begin{array}{l}\text { Nether- } \\
\text { lands }\end{array}$ & 1991Q1-2017Q3 & $\begin{array}{l}11.3339 \\
(0.0003)\end{array}$ & $2008 Q 4$ & $\begin{array}{l}0 \text { vs. } 1 \\
1 \text { vs. } 2 \\
2 \text { vs. } 3 \\
3 \text { vs. } 4\end{array}$ & $\begin{array}{l}22.8194 \\
42.5256 \\
21.0323 \\
19.4542\end{array}$ & $\begin{array}{l}\text { 2008Q4 } \\
2002 Q 3 \\
2013 Q 3 \\
1997 Q 1\end{array}$ \\
\hline $\begin{array}{l}\text { New Zea- } \\
\text { land }\end{array}$ & 1991Q1-2017Q3 & $\begin{array}{l}25.4483 \\
(0.0000) \\
\end{array}$ & 2008Q4 & $\begin{array}{l}0 \text { vs. } 1 \\
1 \text { vs. } 2 \\
\end{array}$ & $\begin{array}{l}55.5195 \\
59.1777 \\
\end{array}$ & $\begin{array}{l}2008 Q 4 \\
2003 Q 3 \\
\end{array}$ \\
\hline Norway & 1991Q1-2017Q3 & $\begin{array}{l}12.4355 \\
(0.0001)\end{array}$ & 2008Q4 & $\begin{array}{l}0 \text { vs. } 1 \\
1 \text { vs. } 2 \\
2 \text { vs. } 3 \\
\end{array}$ & $\begin{array}{l}24.7376 \\
31.0776 \\
24.5743 \\
\end{array}$ & $\begin{array}{l}\text { 2008Q4 } \\
\text { 1999Q3 } \\
\text { 1995Q3 }\end{array}$ \\
\hline Portugal & 1991Q1-2017Q3 & $\begin{array}{l}10.3552 \\
(0.0008)\end{array}$ & 2012Q1 & $\begin{array}{l}0 \text { vs. } 1 \\
1 \text { vs. } 2\end{array}$ & $\begin{array}{l}21.5969 \\
14.9426\end{array}$ & $\begin{array}{l}\text { 2012Q1 } \\
\text { 1995Q1 }\end{array}$ \\
\hline Spain & 1991Q1-2017Q3 & $\begin{array}{l}10.0296 \\
(0.0011)\end{array}$ & 1998Q1 & 0 vs. 1 & 18.1847 & 1998Q1 \\
\hline Sweden & 1991Q1-2017Q3 & $\begin{array}{c}6.7417 \\
(0.0221) \\
\end{array}$ & 2002Q2 & $\begin{array}{l}0 \text { vs. } 1 \\
1 \text { vs. } 2 \\
\end{array}$ & $\begin{array}{l}18.3263 \\
72.7805 \\
\end{array}$ & $\begin{array}{l}2002 Q 2 \\
2011 Q 4\end{array}$ \\
\hline $\begin{array}{l}\text { Switzer- } \\
\text { land }\end{array}$ & 1991Q1-2017Q3 & $\begin{array}{c}5.1795 \\
(0.0819)\end{array}$ & $2002 Q 2$ & 0 vs. 1 & - & - \\
\hline \begin{tabular}{|l|} 
United \\
Kingdom
\end{tabular} & 1991Q1-2017Q3 & $\begin{array}{c}6.3080 \\
(0.0320) \\
\end{array}$ & 2011Q1 & 0 vs. 1 & 29.0001 & 2011Q1 \\
\hline $\begin{array}{l}\text { United } \\
\text { States }\end{array}$ & 1991Q1-2017Q3 & $\begin{array}{l}23.1635 \\
(0.0000)\end{array}$ & 2010Q1 & $\begin{array}{l}0 \text { vs. } 1 \\
1 \text { vs. } 2\end{array}$ & $\begin{array}{l}75.6688 \\
66.2511\end{array}$ & $\begin{array}{l}\text { 2010Q1 } \\
\text { 1998Q2 }\end{array}$ \\
\hline
\end{tabular}

Notes: *differences in data range result from data availability.

p-values in parentheses; both tests with 15\% trimmed data; Bai-Perron test significant on 0.05 level.

Source: own calculations in EViews 10. 
The sequential test results indicate that in the majority of the examined countries there were more breaking dates than one. For example, in Chile three breakpoints were identified: the null hypotheses of 0,1 , and 2 breakpoints were rejected in favour of the alternatives of 1, 2, and 3 breakpoints, respectively. As the scaled F-statistic exceeded the test critical value at a significance level of 0.05 , the test of 4 versus 3 breakpoints did not allow to reject the null hypothesis. The sequential testing procedure also identified $2008 \mathrm{Q} 4$ as a first breaking point in the majority of countries from both groups. These results suggest a structural change in the trade-finance nexus that occurred shortly after the outbreak of the financial crisis. It is worth noting that a structural break in the trade-finance nexus was more characteristic for the middle-income countries. If we refer to 2008 as a breakpoint date, then in 9 (Chile, Czech Republic, China, Hungary, Korea, Mexico, Poland, Russia, Turkey) of the 15 middle-income countries we examined the trade-finance nexus was distorted, whereas only 8 (Belgium, Denmark, France, Germany, Ireland, Netherlands, New Zealand, Norway) of the 21 high-income countries experienced such a break. Including the results of 1 vs. 2 breakpoints in the sequential approach of Bai-Perron test, we may indicate two more countries in each group (Argentina and Brazil in middle-income group, and Finland and Italy in the high-income group) with such a break in 2008Q4 (in these 4 countries the test results suggest 2008Q4 as the second breakpoint). When we take into account that the crisis did not start in all the countries simultaneously, as the trade and financial channels of crisis transmission did not act immediately, a broader perspective can be applied. Including breaking dates from 2008 till 2010, a break in the tradefinance nexus can be identified in almost all of the middle-income countries (12 of 15) and only in a half of the high-income countries (12 of 21).

We suggest several arguments that could explain the structural trade-finance break in the crisis and post-crisis era. In the majority of the high-income countries the reaction of trade and finance was in accordance with the above-discussed hypotheses. This seems to be in line with our supposition derived from the stylized facts. Sharp declines in international trade flows, as well as 'definancialization' were a consequence of the recession, deterioration of private and public sector balance-sheets positions, and prudential regulations imposed on banking, and non-banking financial institutions. As the crisis originated partly from the accumulation of toxic assets in banks' balance-sheets, their reaction forced to a certain extent by macroprudential regulations - was to deleverage. Owing to higher uncertainty and risk aversion, banks were not eager to provide credit to the economy. On the other hand, the enterprises faced investment constraints problem which resulted from the lack of investment projects gaining satisfactory returns on capital (a possible explanation of the secular stagnation hypothesis). Besides, financial markets have evolved in ways that allow firms to raise money through stocks, bonds and wholesale money markets, by-passing traditional bank lending. The high-income countries experienced relatively faster growth of private bond markets, stock markets, mutual funds and pension funds markets than the banking system. Another structural characteristic of the high-income economies is that whereas in the recent 20 years the size of the banking system remained largely stable (in 1993 banking credit to GDP amounted to $90 \%$ and similarly it did in 2016 with a peak of nearly 100\% in 2008), the share of shadow banking system (assets of nonbanks) increased significantly (as a result total credit provided by banks and 
other non-bank financial institutions increased from $120 \%$ of GDP in 2003 up to $150 \%$ in 2016 reaching a peak of $165 \%$ of GDP in 2008).

The middle-income economies, which in the three decades before the outbreak of the crisis had extensively opened their economies, were also severely hit by negative external shocks during the global financial crisis. Their openness shrank from $60 \%$ of GDP in 2008 to $50 \%$ of GDP in 2009 , however, private credit to GDP increased from $56 \%$ of GDP in the $1990 \mathrm{~s}$ to $74 \%$ of GDP in 2009, reaching a peak of $113 \%$ of GDP in 2016 (Figure 5). We explain this as follows. Firstly, despite the crisis, the majority of these countries registered both positive rate of GDP growth (in 2009 average annual rate of GDP growth in middle-income countries was $2.25 \%$ ) and financial development. This seems to be consistent with the demand-following hypothesis, which in its original version assumed that the real sector development drives financial development. Secondly, many of middle-income countries are emerging economies which catch up with high-income economies. Capital accumulation and investment decisions which are underpinned by financial markets are important determinants of this process. Sharp increase in finance development and "trade plateau" evidenced in middle-income countries in the aftermath of the global crisis can be also explained by the fact that many of these economies reached Lewis turning point. It refers to the phase of economic development when urban factories have finally absorbed the labour surplus from rural areas (Koo, 2016). This stage of industrialisation induces higher wages, loss of competitiveness and deterioration in exports. To continue their expansion and development, middle-income countries need innovations, which are finance-intensive. In fact, many emerging market economies, in order to avoid a 'middle-income' trap, started investing in the advanced-technology industries, as well as in human capital.

\section{CONCLUSIONS}

The objective of our article was to examine whether the trade-finance nexus was distorted in the aftermath of the global financial crisis. We tested changes in exports and financial development in 36 countries, of which 15 were classified as middle-income economies and 21 as high-income ones.

The Quandt-Andrews breakpoint test and the Bai-Perron multiple breakpoint test were applied to test for structural breaks in the trade-finance linkages. For the majority of the examined countries the tests showed that a structural break in trade-finance relationship occurred in 2008Q4. We also observed that structural changes were relatively more often identified in middle-income countries than in high-income ones. When we refer to 2008 as a breakpoint date, the trade-finance nexus was distorted in 9 of the 15 middle-income countries, whereas the breakpoint was identified only in 8 of the 21 high-income countries. When we consider the breaking dates from 2008 till 2010, a break in the trade-finance nexus was indicated in almost all of the middle-income countries (12 of 15) and in only a half of the high-income countries (12 of 21) examined. This finding was in line with the stylized facts which showed that adjustments of international trade and financial development in the crisis era differed across countries depending on their level of development.

We are aware, however, of the limitations of the methods employed in the article, which allow only for a rough first approximation of the breaks in the trade-finance nexus. The analysis could be enriched by employing panel data regressions, aimed at 
uncovering differences in the trade-finance nexus between high- and middle-income economies. It is also worth rethinking whether the measures of finance are relevant as the modern financial system has become more and more multifaceted. While banks are typically the largest and most important financial institutions, investment banks, insurance companies, mutual funds, pension funds, venture capital firms, and many other types of nonbank institutions start to play a substantive role. According to Adu, Marbuah and Mensah (2013) and Sare et al. (2018), the empirical results may lead to significantly different conclusions depending on the proxy used for financial development. Therefore, relying solely on the single, bank-centred measure may be a simplification. To overcome the shortcomings of a single indicator of financial development, a comprehensive index capturing both financial institutions and markets could be used, for example that one proposed by IMF (Svirydzenka, 2016).

A structural break in the relationship between exports and financial development supports the view that there were important changes in economic relationships at the end of 2008 , i.e. during the most severe phase of the global financial crisis. Understanding such breaks and their impact on economies needs further research. As the findings on the trade-finance nexus are still inconclusive, the question about the direction of these linkages remains still an intellectual challenge for economic researchers. The future studies in this field of trade-finance nexus could be also enhanced if a larger group of countries in a longer time span, as well as a conceivable endogeneity in this relationship were considered. Moreover, possible non-linearities in the above-mentioned nexus could be included (Gries, Kraft, \& Meierrieks, 2009; Gächter \& Gkrintzalis, 2017). The crisis emphasized the necessity of the revision of traditional theoretical approaches, including those referring to the linkages between the financial and the real sides of economy. The exploration of the nature of the causal relationships between trade and finance would undoubtedly contribute to the interpretation of their role in economic growth.

\section{REFERENCES}

Acemoglu, D. (2009). Introduction to Modern Economic Growth. Princeton, NJ: Princeton University Press. Acemoglu, D., Johnson, S., \& Robinson, J. (2005). Institutions as a Fundamental Cause of Long-Run Growth. Handbook of Economic Growth, 1, Part A, 385-472.

Adu, G., Marbuah, G., \& Mensah, T.J. (2013). Financial development and economic growth in Ghana: Does the measure of financial sector development matter?. Review of Development Finance, 3, 192-203.

Aizenman, J., \& Noy, I. (2009). Endogenous Financial and Trade Openness. Review of Development Economics, 13(2), 175-189. https://doi.org/10.1111/j.1467-9361.2008.00488.x

Andrews, D.W.K., (1993). Tests for Parameter Instability and Structural Change with Unknown Change Point. Econometrica, 61(4), 821-856.

Bahgwati, J., \& Srinivasan, T.N. (2001). Trade and Poverty in the Poor Countries. American Economic Review, 92(2), 180-183. https://doi.org/10.1257/000282802320189212

Bai, J., \& Perron, P. (1988). Estimating and Testing Linear Models with Multiple Structural Changes. Econometrica, 66(1), 47-78. https://doi.org/10.2307/2998540

Bai, J., \& Perron, P. (2003). Critical Values for Multiple Structural Change Tests. Econometrics Journal, 6(1), 72-78. https://doi.org/10.1111/1368-423X.00102 
Baldwin, R., \& Gu, W. (2004). Trade Liberalization: Export-Market Participation, Productivity Growth and Innovation. Oxford Review of Economic Policy, 20(3), 372-392. https://doi.org/10.1093/oxrep/grh022

Baltagi, B.H., Demetriades, P.O., \& Law, S.K. (2009). Financial development and openness: Evidence from panel data. Journal of Development Economics, 89(2), 285-296.

Beck, T. (2002). Financial development and international trade: Is there a link?. Journal of International Economics, 57(1), 107-131.

Beck, T. (2003). Financial Dependence and International Trade. Review of International Economics, 11(2), 296-316. https://doi.org/10.1111/1467-9396.00384

Beck, T., Büyükkarabacak, B., Rioja, F., \& Valev, N. (2009). Who Gets the Credit? And Does it Matter? Enterprise vs. Household Credit across Countries. The B.E. Journal of Macroeconomics, 12(1), 1-44.

Becker, B., Chen, J., \& Greenberg, D. (2013). Financial Development, Fixed Costs, and International Trade. The Review of Corporate Finance Studies, 2(1), 1-28.

Bordo, M., \& Rousseau, P. (2012). Historical Evidence on the Finance-Trade-Growth Nexus. Journal of Banking \& Finance, 36(4), 1236-1243.

Chang, R., Kaltani, L., \& Loayza, N.V. (2009). Openness can be good for growth: The role of policy complementarities. Journal of Development Economics, 90(1), 33-49. https://doi.org/10.1016/j.jdeveco.2008.06.011

Chang, Y., Hung, M.-W., \& Lu, C. (2005). Trade, R\&D Spending and Financial Development. Applied Financial Economics, 15(11), 809-819. https://doi.org/10.1080/09603100500077102

Dollar, D., \& Kraay, A. (2003). Institutions, Trade, and Growth. Journal of Monetary Economics, 50(1), 133-162.

Dornbusch, R., \& Reynoso, A. (1989). Financial Factors in Economic Development. NBER Working Paper 2889, 1-35.

Edwards, S. (1998). Openness, Productivity and Growth: What Do We Really Know?. Economic Journal, 108(447), 383-398. https://doi.org/10.3386/w5978

Frankel, J.A., \& Romer, D. (1999). Does Trade Cause Growth?. American Economic Review, 89(3), 379-399. https://doi.org/10.1257/aer.89.3.379

Gächter, M., \& Gkrintzalis, I. (2017). The Finance-trade nexus revisited: Is the global trade slowdown also a financial story?. Economics Letters, 158, 21-25. https://doi.org/ 10.1016/j.econlet.2017.05.037

Greenwald, B., Salinger, M., \& Stiglitz, J. (1992). Imperfect Capital Markets and Productivity Growth. Paper presented at the NBER Conference, Vail, CO. https://doi.org/10.1016/00142921(92)90084-A

Greenwood, J., \& Jovanovic, B. (1989). Financial Development, Growth and the Distribution of Income. NBER Working Paper 3189, 1-42.

Gries, T., Kraft, M., \& Meierrieks, D. (2009). Linkages Between Financial Deepening, Trade Openness, and Economic Development: Causality Evidence from Sub-Saharan Africa. World Development, 37(12), 1849-1860.

Helpman, E. (1984). A Simple Theory of International Trade with Multinational Corporations. Journal of Political Economy, 92(3), 451-471.

Helpman, E., \& Krugman, P. (1985). Market Structure and Foreign Trade. Cambridge, MA: The MIT Press.

Hoenig, T.M. (1995). The U.S. Economy: A Look Ahead. Federal Reserve Bank of Kansas City Economic Review, 80(1), 19-22. 
Hur, J., Raj, M., \& Riyanto, Y.E. (2006). Finance and Trade: A cross-country empirical analysis on the impact of financial development and asset tangibility on international trade. World Development, 34(10), 1728-1741.

King, R.G., \& Levine, R. (1993). Finance and Growth: Schumpeter Might Be Right. The Quarterly Journal of Economics, 108(3), 717-737. https://doi.org/10.2307/2118406

Koo, R.C. (2016). The Other Half of Macroeconomics and the Three Stages of Economic Development. Real-World Economics Review, 75, 1-49.

Levine, R., Loayza, N., \& Beck, T. (2000). Financial Intermediation and Growth: Causality and Causes. Journal of Monetary Economics, 46(1), 31-77.

Lucas, R. (1988), On the Mechanics of Economic Development. Journal of Monetary Economics, 22(1), 3-42. https://doi.org/10.1016/0304-3932(88)90168-7

Manova, K., (2013). Credit Constraints, Heterogeneous Firms, and International Trade. The Review of Economic Studies, 80(2), 711-744.

Menyah, K., Nazlioglu, S., \& Wolde-Rufael, Y. (2014). Financial development, trade openness and economic growth in African countries: New insights from a panel causality approach. Economic Modelling, 37(C), 386-394. https://doi.org/10.1016/j.econmod.2013.11.044

Rajan, R.G., \& Zingales, L. (2003). The Great Reversals: the Politics of Financial Development in the Twentieth Century. Journal of Financial Economics, 69(1), 5-50. https://doi.org/10.1016/S0304405X(03)00125-9

Robinson, J. (1952). The Rate of Interest and Other Essays. London: MacMillan.

Rodrik, D. (1992). The Limits of Trade Policy Reform in Developing Countries. Journal of Economic Perspectives, 6(1), 87-105. https://doi.org/10.1257/jep.6.1.87

Rodrik, D., Subramanian, A., \& Trebbi, F. (2004). The Primacy of Institutions over Geography and Integration in Economic Development. Journal of Economic Growth, 9(2), 131-165.

Sare, Y.A., Aboagye, A., Mensah, L., \& Bokpin, G. (2018). Effect of financial development on international trade in Africa: Does measure of finance matter?. The Journal of International Trade \& Economic Development. https://doi.org/10.1080/09638199.2018.1474246

Schumpeter, J.A. (1934). The Theory of Economic Development: An Inquiry into Profits, Capital, Credit, Interest and the Business Cycle. Cambridge, MA: Harvard University Press.

Svirydzenka, K. (2016). Introducing a New Broad-based Index of Financial Development. IMF Working Papers, WP/16/5.

Wachtel, P. (2003). How Much Do We Really Know about Growth and Finance?. Economic Review, Federal Reserve Bank of Atlanta Economic Review, 88(1), 33-47.

Zhang, Ch., Zhu, Y., \& Lu, Z. (2015). Trade openness, financial openness, and financial development in China. Journal of International Money and Finance, 59(C), 287-309. https://doi.org/ 10.1016/j.jimonfin.2015.07.010 


\section{Authors}

The contribution share of authors is equal and amounted to $50 \%$ each of them.

\section{Marta Wajda-Lichy}

Master in Economics (Faculty of Economics, specialization: Foreign Trade, Cracow University of Economics); PhD in Economics (Cracow University of Economics), Post-graduate MBA study D.E.S.S (Diplôme d'Etudes Supérieurs Spécialisées in Business Administration), Université de Lille I. Her research interests include international trade, economic integration and economic development of middle-income countries.

Correspondence to: Marta Wajda-Lichy, PhD, Cracow University of Economics, Macroeconomics Department, ul. Rakowicka 27, 31-510 Kraków, Poland, e-mail: wajdam@uek.krakow.pl

\section{Paweł Kawa}

Master in Economics (Faculty of Economics, specialization: Foreign trade, Cracow University of Economics) and Law (Faculty of Law and Administration, field of study: Law, Jagiellonian University). PhD in Economics (Cracow University of Economics). Research interests include economic growth, financial development, economic integration and economic development of middle-income countries.

Correspondence to: Paweł Kawa, PhD, Cracow University of Economics, Macroeconomics Department, ul. Rakowicka 27, 31-510 Kraków, Poland, e-mail: kawap@uek.krakow.pl

\section{Acknowledgements and Financial Disclosure}

The authors would like to thank the anonymous referees and Thematic Editor of EBER for their useful comments, which allowed to increase the quality of this article.

\section{Copyright and License}

This article is published under the terms of the Creative Commons

Attribution - NoDerivs (CC BY-ND 4.0) License http://creativecommons.org/licenses/by-nd/4.0/

Published by the Centre for Strategic and International Entrepreneurship - Krakow, Poland 
